\title{
Translation, Littérisation, and the Nobel Prize for Literature
}

\author{
Kelly Washbourne \\ Kent State University, USA
}

As I proceed, I will from time to time indicate to you where we are in the manuscript. That way you won't lose the thread. This will be of help especially to those of you who don't understand either Italian or Swedish. English speakers will have a tremendous advantage over the rest because they will imagine things I've neither said nor thought. There is of course the problem of the two laughters: those who understand Italian will laugh immediately, those who don't will have to wait for [the] Swedish translation. And then there are those of you who won't know whether to laugh the first time or the second.

Dario Fo, Nobel Lecture (Fo 130)

Writers create national literature with their language, but world literature is written by translators.

José Saramago (Appel 40)

\section{Introduction}

Translation is quite often a precondition for the Nobel Prize in Literature, to the extent that the canonization of a world-class writer can entail in part the canonization of his or her extant translations. One critic inscribes Mo Yan's 2012 win in a network of "collaborators," a process true of most writers working outside global literary languages: " $[\mathrm{H}]$ is prize winning is a success of collaboration with the author as the nodal point amid a necessary global network of cosmopolitanites, including translators, publishers, nominators, readers, [and] the media..." (Wang 178). And yet translation has been largely absent, except parenthetically, in discussions of this highly visible international prize. The translation factor in the decision-making process, and in the identityformation of a candidate, is far from negligible. Writers find their fortunes hanging on the timing, quantity, quality and distribution of translations, and perhaps even the popular success of them. The Prize, moreover, depends not only on translation, but on translation into major European languages, especially but not exclusively English.

The selection process is described laconically by Perry Link as one in which countries "in essence [hand] over judgment of its cultural achievement to a committee of Swedes," a body that voted in Mo Yan although only one committee member, Göran Malmqvist, can read Chinese, while the others relied on translations (Wang 178). At any given time, in fact, only one or two Swedish Academy members comprising the Literature committee has proficiency in non-European languages (Lovell 31). The five members of the Nobel Committee, which serves in an advisory capacity to the eighteen-member Swedish Academy, do, however, have many active reading languages: "We master thirteen languages in the Academy but when we suspect a genius hidden in an unknown language we 
TranscUlturAl, vol. 8.1 (2016), 57-51.

http://ejournals.library.ualberta.ca/index.php/TC

call on translators and oath-sworn experts to give us generous samples of that writer" (Parks and Wästberg). Gyllensten writes:

[Proposed authors'] works are procured in the original or in translation, if they are not already in the [Svenska Akademiens Nobelbibliotek, the Nobel Library]. In cases where there is a paucity of translations and where candidates write in a language unfamiliar to the Academy's members or the experts, sample translations can be commissioned. (9)

The reliance on expert informants for their qualitative valuations can very easily devolve into campaigning and logrolling that compromise any objective measures of literary qualification. ${ }^{1}$ Parks invites us to conceive of the Babelian incommensurabilities of reading and comparing hundreds of texts from multiple languages (Parks and Wästberg; see also Parks 2011):

[1] magine our Swedish professors as they compare a poet from Indonesia, perhaps translated into English, with a novelist from Cameroon, perhaps available only in French, and another who writes in Afrikaans but is published in German, and then a towering celebrity like Philip Roth, whom they could of course read in English, but they might equally feel tempted, if only out of a sense of exhaustion, to look at in Swedish. ${ }^{2}$

Parks' point is that translation, rather than equalizing opportunity, only serves to show the incomparability of the authors. Translation may even exacerbate the situation by offering the illusion of a level playing field. The committee masters thirteen languages, but collectively, not individually. Feldman (60) is forthright in assessing the assessors:

The fact is that the Swedish Academy lacks the linguistic competence needed for a truly international jury, which is not surprising. Perhaps only three or four of the greatest universities in the world would have such resources. Unprepared to read fluently and directly in major and populous languages such as Chinese, Arabic, or Hindi, not to mention the minor ones, the Nobel committee is overly dependent on translations, whose occurrence and quality are notoriously capricious.

"Overly dependent on translations" may not in itself invalidate a cross-cultural evaluation of a candidate. Reading in translation has been held to be a proven methodology (see Aldridge's defense, 24-5, which cites landmarks of research conducted via translations), although critics such as Spivak decry homogenizing translation practices to which otherness is submitted. That debate cannot be overlooked in our discussion. The larger, unseen flaw, however, lies in that some voters

\footnotetext{
1 Man Booker International has an advisory network, an e-Council, which winnows the field and makes recommendations. We can assume that unlike commissioned translators or advisors to the Nobel, they swear no oath of impartiality; on the contrary, prize giving universally works on the "adversarial system."

${ }^{2}$ Feldman (6) repeats a claim that Claude Simon's candidacy was helped greatly by a Swedish translation just before the award (1985), despite his writing in French.
} 
who do not master some languages will necessarily rely on different means than others for their perception of a given writer. In other words, complicating Parks' scenario, perhaps Philip Roth is evaluated by some in the English, by others in the Swedish, by still others comparing the two, and by some who read translations of the texts from multiple languages. These divergences in reading methods compound the translation quality variable. ${ }^{3} \mathrm{~A}$ well-represented writer in accessible languages will make a stronger impression, moreover, than one represented only sparsely; by extension, a wider sample is a truer representation of the spirit of the award, which is not given for individual publications but for a body of work, albeit sometimes the corpus is quite reduced, and deliberations may focus on a couple of excellent texts (e.g., two novels by Kawabata, according to Wade, or even a single work ${ }^{4}$ ). Translations have been produced by the Academy members themselves (Espmark 80; 139; Leverence 404), a fact which has the appearance if not the substance of a conflict of interest, inasmuch as it is the rare translator who would feel no advocacy for his or her own translations. ${ }^{5}$ Pablo Neruda's Swedish translator, Academy member Artur Lundkvist, championed the poet's work for decades. Indirect translation of Nobel candidates, such as the Turkish Orhan Pamuk's works from Turkish into Swedish via English (Ringmar 6), is not unknown. Translations reviewed by the panel may be of uneven quality, a factor that seems nowhere to be accounted for, at least formally, although one surmises that expert consultants to the deliberations surely make this case.

The question remains as to how swearing an oath provides quality assurance in the literary domain. Apart from eliminating the chance of outright fraud, this measure seems to be an insufficient safeguard of quality in the creative arts. But then, the Prize has always been a matter of legal executorship as much as of literary appraisal: "Indeed, the history of the literature prize is in some ways a series of attempts to interpret an imprecisely worded will” (Espmark 3). The key word in Nobel's will-idealisk (ideal) — has prompted much exegetical and legal argument. Did he mean

\footnotetext{
3 Translations and non-translations competing head to head do not present an unprecedented situation. For example, the Man Asian Literary Prize is given to an Asian writer writing in English or translated into English, thus translated works theoretically could compete with English language originals (http://www.manasianliteraryprize.org/about-us). Many broad classes of literature accommodate both in the same system: Damrosch's world literature itself includes those works that "circulate beyond their culture of origin, either in translation or in their original language" (4).

4 "Especially in the early days, and in any case no later than Sholokhov's 'epic of the Don' in the citation of 1965 , the Academy often pointed out a single work as the main reason for the prize. The other eight books mentioned in this way are Mommsen's A History of Rome, Spitteler's Olympian Spring, Hamsun's Growth of the Soil, Reymont's The Peasants, Thomas Mann's Buddenbrooks, Galsworthy's The Forsyte Saga, Martin du Gard's Les Thibault, and Hemingway's The Old Man and the Sea" (Allén). There is some evidence, too, that Tagore, though a towering presence in Bengali literature, was but a cipher throughout the rest of the world; his reputation could not have been helped by the author's self-translation of his poetry (see Chakraborty; Cordingley). Collins also makes the case that Tagore was awarded the Nobel for more than Gitanjal (despite the often-repeated assertion that that book alone was responsible), that the Committee could in fact read the original Bengali, and that Yeats had not, then, had quite as strong a hand in revising Tagore's self-translation as was thought.

${ }^{5}$ Gabriela Mistral, according to Nobel judge Sven Hedin, was awarded the Prize in 1945 on the strength of Hjalmar Gullberg's translation into Swedish of all of her verse, then his swaying of the jury's vote (Leverence 404).
} 
idealistik [idealistic]? Did he mean edifying, critical of the status quo, optimistic? ${ }^{6}$ Strindberg criticized the very first Nobel winner, Sully Prudhomme, for having translated the first book of Lucretius' De Natura Rerum, a work of philosophical pessimism. A translational affiliation, in other words, placed the Laureate on the wrong side of edifying literature. Franz Kafka and the inevitable list of outrageously omitted names over the twentieth century, then, did not fulfill the Nobel "skopos."

As we noted above, the quality, number, timing, and language of translations, both commissioned and published, have affected Nobel outcomes. Maurice Edgar Coindreau's Faulkner in French was important to the American's win, just as French has literally been the pivot language for perennial hopeful Ismael Kadare's heightened international profile. ${ }^{7}$ Salvatore Quasimodo "depended crucially on a brilliant English translation by the American poet and translator Allen Mandelbaum, which came out at the opportune moment" (Feldman 104). Feldman further claims that "poets from minor European languages are at a disadvantage-if the Polish Szymborska had not been available in German and Swedish translation, would she ever have won?” (85). Flemish writer Louis Paul Boon's epic De Kapellekensbaan (Chapel Road) was nominated on the strength first of a translation to English, then into Swedish (Vanderauwera 63), a reminder that successful translations - like literary prizes — are an advertisement for more translations. Nadine Gordimer, the 1991 Laureate, had more than fifty years of Swedish-language readers (Gullin 113), certainly a factor in her award, although Gullin concludes that despite poor Swedish translations, the South African's strong reputation in English "automatically transferred to the translations" (125). And Theodore Dreiser's failure in Swedish translation-An American Tragedy sold fewer than 200 copies the first year-may have cost him the Prize, despite thirteen translations in Scandinavia in three years (192730) (Arthur 64).

A lack of translations, or poor translations, can hinder a writer's chances as well. Anderson, for instance, notes that Pramoedya Ananta Toer was the big hope for Southeast Asia but was "illserved by old friends who decided to rush out an English translation of the Buru Quartet....," and that the writer's best work had gone untranslated (108). Not enough of Junichiro Tanizaki's work had been translated when he was nominated (and a finalist) in 1960; by 1965, much of it had been but it was too late- he had died, disqualifying him (Boardman Petersen 50). Countryman Nishiwaki Junzaburo may have lost due to a lack of translations (Hirata xviii). Allen (202) complains that too few translators and specialists are qualified to take on Arabic literature, that the selections are full of omissions and overrepresentations (e.g. too many Egyptian novels, to the detriment of other countries' traditions), and that larger publishing houses do not engage with this body of literature. The works that did appear in translation, those of Naguib Mafouz for example, came "out of

\footnotetext{
${ }^{6}$ The relevant phrase in Nobel's will is usually translated "the most astounding work in an ideal direction" ("The Will"). For a thorough analysis of different parsings of the sense, see Allén.

7 Translation has figured, and will continue to figure, especially prominently in Kadare's international trajectory, though he has not (yet) won. Kadare disguised The Shadow as a translation in order to smuggle it out of Albania. Publishing abroad, in French, was a way of keeping a measure of control of his work under the Hoxha dictatorship (Morgan 38-9), in essence creating new originals in French that would be impervious to the censor's hand (Morgan 40).
} 
sequence" and focused on lesser works (303). Masterful translations of maqama or qasida, it should be noted, too, stand less of a chance than a body of second-rate translations of a commercial Western form such as the novel, which has ascended in the "hierarchies of legitimacy," in Bourdieu's (86) term. Poor translation of Frédéric Mistral's Mirèio may have led to a compromise shared award with José Echegaray in 1904 (Espmark 122). And the first translation of Hungarian writer Imre Kertész's 1975 work, Sorstalanság (Fateless, trans. 1992), was translated in a simplified text that the author himself criticized. It was not until 2002, when he won the Prize and was a much better known writer, that more accomplished translations could be undertaken; by 2004 they were complete (Tötösy de Zepetnek and Vasvári 10). The cases of Stefan Żeromski (1864-1925), Konstantin Balmont (18671942), and Taha Hussein (1889-1973) were decided-unfavorably for the candidates-on translations that did not meet the expectations set by the accolades found in experts' reports. Ivan Bunin's (1870-1953) eventually successful bid was delayed years for the same reason (Asaid). The broad problem is acknowledged openly:

Over the years, the significance of translation has been a recurring theme in the [Nobel] reports. The doubts felt by the 1920s committee over Kostis Palamas is closely related to the difficulty of assessing the language of the original works. In 1931 it was expressly confirmed that the award to Bunin "shall relate to the works as they exist in their original language." It had been difficult for the members to understand the "stylistic mastery" attributed to Bunin by his countrymen. (Espmark 140)

Moreover, there were few translations from non-European languages in the early years of the Prize, a "structural hindrance [that] surely explains why China (Lu Hsin, for example or Lu Ling) and Japan (Siseki, Akutgawa, Tanizaki) were not plausible candidates..." (B. Anderson 101-2). The case of Chinese literature is illustrative of what Casanova calls a "dominated language" (4), defined as having broad diffusion but little recognition in the international market. China's "Nobel Complex," its obsession with failing to win for a full century, has been interpreted as reflecting its insecurity in wanting recognition from the West while at the same time feeling incensed that their own dominance is not acknowledged (Lovell 5-7). Lovell argues that this position shows the tensions attendant upon the country's move toward global self-positioning (Lovell 5-7). Ironically, the "Nobel Complex" may have been triggered by foreign translators promoting Bei Dao's work internationally, and courting the Swedish Academy (113-4), prompting similar campaigns from the literary establishment. The one-hundred-year drought, broken only in 2000, was blamed on poor translations (Ogden 349; Barme ix) or the absence of them altogether.

Translators play a significant role in shaping reception of a Nobel in another crucial way: championing, and explicating, the writers' work in paratextual writings, for example, Howard Goldblatt's chapter in Mo Yan in Context. Some translators, too, helped their own Nobel cause by self-translating (Brodsky, Beckett) or by producing groundbreaking translations, sometimes even of other Nobels. One (future) Nobel translated another, for instance, when Juan Ramón Jiménez collaborated with his future wife on Rabindranath Tagore's Stray Birds into Spanish (Palau de Nemes 
187). Odysseus Elytis, Derek Walcott and Seamus Heaney are a few of the most notable examples of first-rank Laureate translators. Translating of course is inescapably political: Auden was said to have angered the Swedes with a careless and impositional translation (Hoge), and Boris Pasternak's translations served as a veiled and permissible way of expressing dissent via a foreign writer (e.g. Shakespeare's Hamlet, sonnet 77). Thomas (64) shows how Pasternak through his coded translation of Hamlet created a subtext critical of the Stalinist regime. Rabindranath Tagore's self-translated Gitanjali played a decisive role in his 1913 Nobel, for no judge knew the original Bengali (see also n4). He later lamented his own highly paraphrased English version of the work (Cordingley 35), but he had become famous in English, the language which served as a new source-not his original Bengali-for further translations in the West and into Indian languages (Mukherjee 118).

\section{Nobel Criteria: Fixed but Shifting}

Criteria for selection of the Nobel Prize in Literature are known, although they are interpretable and do shift in focus (from modernist humanism to literature of witness, for example, as Engdahl traces) and in selection bias (the awards have been, in Benedict Anderson's words, "contaminated by national politics, the formation of literary cliques, religious convictions, racial prejudices, double standards and ideologies" [99]). The priority has moved pendulously from Scandinavia, to Europe, then finally to sites of postcolonial writing (Mukherjee 118).

Nobel's hope was that the Prize would "have the effect of making a good piece of work known in much wider circles than would otherwise have been the case" (Österling 94). Arguably he foresaw translation as a means of facilitating that circulation. And one member of the Committee, Osten Sjöstrand, articulated in 1981 that "we choose writers who we feel are important to literature in languages other than their own" (Kostelanetz 32). One disadvantage for candidates is that translation takes time, something that can delay the hopes of not only individual writers but whole nations. Though absent in Nobel considerations, transcending space and time has been a factor in making aesthetic discriminations as long ago as Hume's 1757 essay on taste (Ginsburgh). Literary laureateship is judged not on the enduringness of an author's oeuvre but on his or her accomplishments "during the preceding year," which has had two implications for the awards: first, the author must be alive when nominated (translation or retranslation cannot resurrect the chances of a forgotten but worthy dead writer); second, the award is made for recent achievements. The Nobel, like many prizes, is tied to the aura of the living writer, rather than to the survival of the work or reputation of past masters. Nominations have been geopolitically motivated, perhaps none more than the CIA's sending of Boris Pasternak's work in time for consideration for the 1958 Prize, as Ivan Tolstoi controversially claimed and as Finn and Couvée recently confirmed based on newly declassified documents. The original Russian was smuggled into the USSR as a propaganda tool after having been smuggled out for translation (see Finn and Couvée).

Despite universalist rhetoric, the Committee has attempted, via translation, to understand what the literary work means in its local signifying system. In other words, translation in the Nobel 
process is implicitly provided for, and intended, in this conception, to serve not only as a way of representing a text but of accessing its primary reception, as an ad hoc appliance to try to see the work as its original audience did. ${ }^{8}$ Kjell Espmark quotes a 1922 report that warns:

There is a real danger in the Nobel Prize, intended for the richly varied literature of the whole world, awarded by Nobel's countryman, gradually being limited to a less universal circle, if our greater or lesser ease of access to the individuality of the different national spirits should affect our judgments. It is a matter of being on guard and assessing what is foreign to us not simply according to our own demands but according to its own conditions, and according to what we can gather of what it means where it has been created. (Espmark 134)

Yeung calls for reading as "world readers," which she describes as establishing "empathy with unfamiliar Others," ideally aided by a translator's "footnotes, paratextual material, thick translation" or other means (166). Similarly, in evaluating Chilean Gabriela Mistral (1945), Per Hallström sought to understand the "emotional differences" between Latin Americans and Swedes and looked for "genuineness in foreign dress" (136-7). To accomplish this empathic perspective, one can speculate, requires overcoming essentialist assumptions about a national babitus, ${ }^{9}$ and determining whether differences belong instead to the language or the particular writer rather than to the nation.

Hallström's criterion, moreover, would be challenged by writers in exile who abandon their national language and culture and strive for a more universalist vein of writing. Gao Xingjion, a French citizen whose works were banned in his native China, wrote deliberately for an international readership. Upon finishing the manuscript for Cold Mountain, a key work in his Nobel award, he delivered it to a Swedish friend on the Nobel Committee to be translated, and in fact the translation appeared before the Chinese original did in Taiwan (Ding 148-9). And the first African Nobel in literature, Wole Soyinka, who writes in English and draws on Yoruba traditions, criticized cultural nationalism as "neo-Tarzanism," and had perhaps been more of a success in Britain than in Africa (English 301).

The difficulty, then, lies in evaluating world literature with local roots (English 303) as it becomes rearticulated as its own global category that may, in fact, "flout national hierarchies of prestige" (English 305). Boes writes that we read with the ingrained habit, however, of seeing authors as "spokespeople for their respective national communities" even when they have disavowed them, and thus, for example, J.M. Coetzee's Waiting for the Barbarians "would surely have met with a very different reception had it been written by a Swedish author" (n.p). National narratives often travel with their writers in translation.

\footnotetext{
${ }^{8} \mathrm{I}$ have encountered no evidence that a translation specially commissioned for Nobel deliberations was subsequently marketed commercially. Absent such evidence, Nobel translations would mostly be a kind of unpublished ephemera in the classificatory company of cribs and unpublished drafts.

9 The term is Norbert Elias's.
} 
One overlooked aspect of Nobel criteria that has implications for translation is that for the first forty years of the Prize, the Academy endured criticism from the intellectual elite for a simple reason: its choices reflected a projection of an ideal reader as a member of the general public rather than as a professional literary scholar, a focus which shifted in the latter half of the century (Engdahl 324) from "literary entertainment" to "serious literature" (Engdahl 326). Driscoll (43) shows how the Nobel ultimately can be tied to aspirational and entrepreneurial practices that make of the Prize a "new literary middlebrow," at the crossroads of high culture and commerce. The twenty-volume Leather Bound Deluxe Edition Nobel Prize Library (1971; Helvetica) perhaps demonstrates this "equivocality" — in English's term (7) —of a "uniquely aesthetic form of value [subject to] the most businesslike system of production and exchange," or the uneasy meeting of consecration with desecration (Driscoll 31). Such cultural offerings notwithstanding, from a commercial capital standpoint, the Prize widened in its universal scope, becoming more geographically inclusive, but became narrower in the public interest its Laureates and their elite cultural capital could expect to garner. Nobel nominations, after all, come from specialists, not the public, and an unknown but no doubt statistically significant number of these professionals are the nominees' translators. Even with the increased sales most winners earn, at least immediately subsequent to the Prize, the authors' cultural acclaim is only infrequently also mainstream success or celebrity. The notable exceptions are Herta Müller, Hermann Hesse, John Steinbeck, Ernest Hemingway, Pablo Neruda, Gabriel García Márquez, and Jean-Paul Sartre, though the latter refused the Prize. Publishers, translators, scholars, and other stakeholders in the transnational culture industry play roles in the omissions, exclusions, commissions and inclusions of the "canon within the canon," we might call it, composed of the Nobel elite, a literary field unto itself.

\section{Translation and consecration}

Horace Engdahl, former permanent secretary of the Academy, uses the word "beatified," or a second-order immortality, to describe the symbolic power of the literary Nobel (325). Similarly, Casanova ("Consecration and Accumulation" 135) writes of "the great consecrating translators" whose work turns minor languages and literatures into global literary languages. The operative metaphor of consecration offers telling insight into the effect of translation: it performs the purifying rite of making something holy. The translated text, like the lionized author's work, is endowed with a spiritual power, a grace, whereby the work loses its profaneness; a transformation of languages becomes the transformation of prestige. Using the language of paganism and the occult, Casanova writes: "Literary transmutation is achieved by crossing a magic frontier that allows a text composed in an unprestigious language_or even a nonliterary language, which is to say one that either does not exist or is unrecognized in the verbal marketplace - to pass into a literary language" ("Consecration and Accumulation" 136). We can recognize the first phase of Nobel meritoriousness in the aura that surrounds literariness ("Consecration and Accumulation" 135): 
The notion of literariness, which is to say the literary credit that attaches to a language independently of its strictly linguistic capital, makes it possible to consider the translation of dominated authors as an act of consecration that gives them access to literary visibility and existence. Writers from languages that are not recognized $[. .$.$] as literary are not immediately$ eligible for consecration. The condition of their works' being received into the literary world is translation into a major literary language. For translation is not simply a form of naturalization (in the sense of exchanging one nationality for another), or the passage from one language to another; it is much more specifically, a littérisation.

If these works are translated, then, Margulis and Nowakowski (1996) ask incisively about what happens in the colonizing or decolonizing of the translating language and its effects on how a language of resistance operates in the source text:

[D]oes the author choose to work in a local language or a major European one? If the former - how does the work get translated and by whom? What might the translation have done to the work? What kind of semantic processes of abrogation/deformation and appropriation/reformation occur in the work ${ }^{10}$

Casanova points out (The World Republic 154) the "ambiguous enterprise" translation entails, inasmuch as it permits entry into the "republic of letters" at the same time as it imposes a selfdefined universality. Or as Ponzanesi speculates, a risk exists that a price must be paid for worldwide accessibility: "the reduction of difference to an exotic commodity" (7). Accessibility, of course, entails a huge precondition: that those writing in vernacular languages themselves have access to publishers - or translators - in the metropolis at all (Ponzanesi 95), a task made more complicated if the writers work in traditional oral discourses (Ponzanesi 102).

Benedict Anderson, apropos of the dynamic Casanova describes above, writes of Southeast Asia's linguistic factionalism and lack of "solidarity in the face of Stockholm" (106). "None of the national languages of Southeast Asia," he argues, "has a translational aura. The global system makes sure that Burmese, Vietnamese, Lao, Thai, Khmer, Tagalog and even Malay are for 'local users only'," and he blames the "nationalist-philistine ruling elites" (Anderson 106) for not reading good literature and not training translators. Mazrui is outspoken on this score, arguing that the very fact of participating in Nobel candidature means doing so "through the imperial language of the Other" (158), recalling Ngugi wa Thiang'o's (1986) objection to the asymmetry of translation traffic. Mazrui critiques African "lingo-intellectual dependency" (158) on English, as he exposes the exclusionism of the Nobel language hierarchy:

\footnotetext{
10 The authors are using abrogation and appropriation based on Ashcroft, Griffiths and Tiffin's senses: abrogration 'is a refusal of the categories of the imperial culture, its aesthetic, its illusory standard of normative or 'correct' usage, and its assumption of a traditional and fixed meaning 'inscribed in the words" (38); appropriation "is the process by which the language is made to 'bear the burden' of one's own cultural experience... Language is adopted as a tool and utilized to express widely differing cultural experiences (38-39)."
} 
A Japanese may win the Nobel Prize for works written in Japanese; [...] a Frenchman for genius of expression in the French language; and an Egyptian for creative accomplishments in Arabic. However, for the foreseeable future, the Nobel Prize for Literature is unlikely to be awarded for brilliant use of an indigenous African language. (158)

When a non-translating culture also uses a global literary language, another kind of exclusion from translation awards develops. Engdahl stated to a great uproar in the U.S. literary scene that American writers are "too sensitive to trends in their own mass culture... The U.S. is too isolated, too insular. They don't translate enough and don't really participate in the big dialogue of literature. That ignorance is restraining" (Flood). A translational aura, to extend Anderson's term to AngloAmerican letters, we might say depends upon thinking relationally rather than hegemonically, regardless of the dominance of one's language tradition.

Casanova curiously whitewashes criticism of the Academy's choices, noting that its picks have met with "remarkable and uninterrupted approval," and a "monopoly on worldwide literary consecration" ("Consecration and Accumulation" 147). In a loose sense this is true, but always with pockets of resistance and signs of squandering its goodwill and authority: the incoming permanent secretary of the Swedish Academy Peter Englund confessed in 2009 that the panel has been too "Eurocentric" (Rising); the very first award to Sully Prudhomme was controversial; Tolstoy was overlooked [1901], as of course Woolf, Rilke, Ibsen and all of Brazil perennially would be; Elvyind Johnson and Harry Martinson (1974) won over Graham Greene and Vladimir Nabokov; August Strindberg was given a crowdfunded "Anti-Nobel Prize" when he failed to win; and members of the committee have resigned in protest at certain choices (e.g. the Austrian Elfriede Jelinek in 2004). Thomas Beebee probably comes closest to the truth in writing that there are polar reactions to the Nobel Prize: "loyal acceptance and instrumentalization of the Swedes' choices" or a "demystifying' approach that denies any relation between the Academy's choices and reality" (139).

The Nobel's authority to confer prestige is challenged not only by critiques of its selections but by the Bourdieusian field of struggle between literary prizes to be the "ultimate consecrator" (Driscoll 122, after English 62). And yet the "systems of sponsorship, evaluation, and consecration by means of which power euphemises itself as merit (as intrinsic and proper rather than imposed and arbitrary) and thereby secure its symbolic efficacy" proliferate (English 111, emphasis mine). ${ }^{11}$ Lovell finds that the very existence of the Nobel militates against Goethe's idea of "universalistic world literature [that] would not require arbitration by the possessors of wealth and power" (28), although one must concede that the Prize at times is conferred on anti-establishment writers who decry their national politics. In parallel to the Nobel's locus of privilege, our era has seen the precipitous rise of competitions such as the Neustadt International Prize for Literature, the Independent Foreign

\footnotetext{
${ }^{11}$ Many aspects of the Nobel deliberations are off the record; nominations are publicly available after only fifty years. Power and secrecy are mutually reinforceable.
} 
Fiction Prize, the Franz Kafka Prize, the Prix Goncourt, the Prix International, ${ }^{12}$ the Man Booker International Prize, and the International IMPAC Dublin Literary Award (for which submissions must have been published in English or English translation; if a translated work wins, the author shares the prize with a translator). ${ }^{13}$

The Man Booker in some ways has differentially marketed itself against the Nobel: its administrators have "insisted on [its] international quality, on its translinguistic recognition, and on its emphasis on literary merit alone" (Thacker 554), perhaps the last point serving to chastise the Nobel arbiters for failing to function as a meritocracy. Man Booker International has the requirement, moreover, that translations already exist and that works be "generally available in translation." In other words, to be eligible for the prize means to have already been discovered in translation, to be successfully 'littératised. Some international literary prizes have shone a spotlight on writers who were translated as a result, and ultimately these awards have proven to be a path to the Nobel.

As Riggan reminds us: "Current fame is not a major criterion. Quality is. The Nobel Prize in Literature is not intended merely to echo and confirm popularity [but] to attempt to point out talent not yet recognized..." (405). When observers complain that they have never heard of a given awardee, they are engaging in an inductive fallacy: an honoree unknown to them more likely means not that the winner is an unmerited choice, but that more translation and dissemination are needed. Engdhal reminds us (327) that no shared vision exists as to who ought to be canonized, and that it is especially easy from within the global powers to fall prey to the illusion that one's own country's luminaries, or view of another's, are shared by all. (Consider that Sinclair Lewis's win has long been attributed to Swedish desire to consume and privilege an image of Americans as Babbitts: grasping, materialistic, and petty [Arthur 64; C. Anderson]). Sarah Lawall provides the watchword in calling for "[scrutiny of] not only the foundation of any prize claiming global status but, more importantly, the complicated signifying practices, claims of representation, and subtly offered schemas of value that are bound up in the award itself" (27). The Nobel, to Lawall, ought to be a "space of exchange" for dialogue within the writer's own tradition at the same time it produces conversation between cultures on a "shifting but common ground" (27).

The collateral effects of Nobel prize giving are difficult to gauge. But we can ask ourselves: How many works are translated not as a result of the Nobel, but in a bid for it? How many readers

\footnotetext{
12 Pickford recounts some of the challenges presented by perceptions (before 2008) that the Prix had conflicts of interest (panelists with ties to publishers) and other problems in becoming an agency of legitimation.

${ }^{13}$ http://www.impacdublinaward.ie/. The Man Booker International Prize $(£, 60,000)$, perhaps even more progressively, allows the winning author to choose a translator to win $£ 15,000$ (http://www.themanbookerprize.com/feature/manbooker-international-prize-and-translation). The Independent Foreign Fiction Prize (UK; f,10,000) for contemporary fiction in translation goes even further, being split evenly between the writer and the translator. Even some continentwide contests such as the Caine Prize for African writing admits translations, with prize money to be shared with the translator (Ponzanesi 101-2). Daniel Weissbort throws down the gauntlet by calling for no less than a Nobel Prize for Translation, but prize sharing goes a long way toward recognizing the translator's role.
} 
TranscUlturAl, vol. 8.1 (2016), 57-51.

http://ejournals.library.ualberta.ca/index.php/TC

have endured the trials of learning a foreign language well enough to read a translationally underrepresented Nobel in the original? More concretely, the Nobel Library, a library of literary translations, in part, is another positive externality of the Prize, as democratic dissemination of the works loaned through this resource form a "work in an ideal direction" beyond anything prescribed in the founder's will.

\section{Conclusion}

The conferring of the literary Nobel Prize rewards translation success, indicates translation gaps, and motivates translation production. Translation determines to a largely unrecognized extent the consecration of international literary figures, and in turn is driven by the economic opportunity that arises once the consecration is achieved. Many Laureates' best work is behind them when they win, though their best work in translation often lies ahead of them.

We have considered some of the contingencies, gaps, subjectivities, and irregularities of translation production and assessment for the Nobel and the imbalance of trade relations between the core, periphery, and semi-periphery, terms Heilbron uses to describe the role and number of translated works into and out of given languages in the hierarchical but interdependent structure of a world translation economy. Much more work can be carried out with respect to translations before and after the Prize: book sales as measured by BookScan (Nielson) and other reporting systems, circulation figures, and demand over time; whether the long-term canonicity of writers is affected; the extent to which a Nobel' recipient's fellow countrymen are translated more after a win; ${ }^{14}$ the marketing of the Nobel works as commercial and symbolic capital, for example in reissuances of back catalogues; the impact of book fairs, national patronage of translations "for export" or of foreign literature "for import"; literary translation prizes on the national level that support Nobel chances, such as the Korea Times' promotion of Korean literature; and overrepresented writers (Pablo Neruda) and works (some nine English versions of Juan Ramón Jiménez' Platero and I published in the twentieth century). In-depth studies of particular Nobels' identity formation in translation would be welcome. One especially fruitful direction for inquiry is the study of post-

\footnotetext{
14 See Gunder, who details a project, "The Nobel Effect," investigating some of these avenues of inquiry. Gunder is careful to note that isolating such an effect amidst multivariate factors and causations, each different for each author and era, is difficult, and thus must contain vast data drawing on different prizes and language combinations (108). The author surveyed Swedish translations of Icelandic literature, in particularly the Laureate Halldór Laxness, and found no "Nobel Effect," demonstrating the need for more data to confirm or disconfirm the hypothesis that the Nobel results in more transnational recognition in the form of translation; Icelandic-English might have shown more robust results.

Claims such as Aboul-Ela's, for example — that Naguib Mafouz's win in 1988 became "an obstacle for younger Arab writers and their attempts to get the attention of self-satisfied publishers, who prefer the Nobel Laureate's 'proven record' in U.S. markets" (42)—demand our attention. If empirically true, publishers have developed unreasonable expectations for all but the rare blockbuster Nobels. Huggan also concludes that postcolonial literatures have broken through, to the detriment of the many who remain obscured by what we might call the "star system" of big names appearing in translation and occluding those who would follow.

It is not only underrepresented languages that meet this fate. Even well-known Laureates such as Solzhenitsyn have works not yet translated into English (Kalder).
} 
Nobel readings of a writer's work; Fayen (following Emerson), for example, shows how Faulkner's work was revisited after the Nobel in light of his Nobel acceptance speech, which retrospectively added a moral dimension to his previous writing, and a level of quality hitherto unseen, in critics' eyes (90). Translators' strategies changed as well: before the Nobel, Latin American translators had "improved" Faulkner, but by the 1950s were no longer conforming to their own cultural norms but deferring in their choices to Faulkner's authority and individual style, which now were held to be inviolable (Faven 134-5).

It may seem to be much ado every October over 8 or 10 million kronor, a gold medal and a diploma, but far more is at stake, including the fortunes of translators, publishers, readers, and the compatriot writers who follow in the Laureates' wake. Prizes, as part of the intertextual "discourse of celebration" (Roberts 6-7) of a text, are also part of a text's reception (Roberts 6-7). We are reminded how the Nobel presents, in microcosm, a drama of how we evaluate not only texts but representations of them made by others in the competitive marketplace of ideas. Just as there is no neutral translation, neither is evaluation ever free of the enforcement of or resistance to a system of values, in the dynamics of which translation is a catalytic factor. We are reminded each year, in short, of the power structures of the "literary-value industry" (English and Frow 45)—what Beebee calls the material facts of world literature (140) as it is made, promoted, translated, exchanged, circulated, judged, and prized-visibly and invisibly shaping taste and the symbolic capital that these gatekeepers oversee. 
TranscUlturAl, vol. 8.1 (2016), 57-51.

http://ejournals.library.ualberta.ca/index.php/TC

\section{REFERENCES}

Aboul-Ela, Hosam. "Challenging the Embargo: Arabic Literature in the US Market." Middle East Report 219, Summer (2001): 42-44. Print.

Aldridge, Alfred Owen. The Reemergence of World Literature: A Study of Asia and the West. Newark: University of Delaware Press, 1986. Print

Allen, Roger. “Arabic Literature and the Nobel Prize.” World Literature Today 62.2 (1988): 201-3. Print.

Allén, Sture. "Topping Shakespeare? Aspects of the Nobel Prize for Literature." Nobelprize.org. Nobel Media AB 2014. Web. 7 January 2015.

Anderson, Benedict. "The Unrewarded: Notes on the Nobel Prize for Literature." New Left Review 80 (March-April 2013): 99-108. Print.

Anderson, Carl L. The Swedish Acceptance of American Literature. Philadelphia: University of Pennsylvania Press, 1957. Print.

Appel, Anne Milano. "Out of the Shadows: Unionizing in Rome." The ATA Chronicle 36.10 (2007): 38-44. Print.

Arthur, Anthony. Literary Feuds: A Century of Celebrated Quarrels from Mark. Twain to Tom Wolfe. New York: Thomas Dunne Books, 2002. Print.

Asaid, Alan. “Översättaren sätter prägel på Nobelpriset.” Svenska Dagbladet, 17 July 2008. Web. 14 August 2015.

Ashcroft, Bill, Gareth Griffiths, and Helen Tiffin. The Empire Writes Back: Theory and Practice in PostColonial Literatures. New York: Routledge, 1989. Print.

Barme, Geremie. In the Red: On Contemporary Chinese Culture. New York: Columbia University Press, 1999. Press.

Beebee, Thomas Oliver. "From Nobel to Nothingness: The Negative Monumentality of Rudolf C. Eucken and Paul Heyse." German Literature as World Literature. Ed. Thomas Oliver Beebee. New York: Bloomsbury, 2014. 137-56. Print.

Boardman Petsen, Gwenn. The Moon in the Water: Understanding Tanizaki, Kawabata, and Mishima. Honolulu: University Press of Hawaii, 1979. Print. 
Boes, Tobias. "Thomas Mann, World Author: Representation and Autonomy in the World Republic of Letters." Seminar: A Journal of Germanic Studies 51.2 (2015): 148-172. Web. 14 August 2015.

Boon, Louis-Paul. De Kapellekensbaan. Amsterdam: De Arbeiderspers, 1953. Print.

Bourdieu, Pierre. Distinction: A Social Critique of the Judgment of Taste. Cambridge: Harvard University Press, 1984. Print.

Casanova, Pascale. "Consecration and Accumulation of Literary Capital: Translation as an Unequal Exchange." Translation Studies: Critical Concepts in Linguistics. Ed. Mona Baker. Vol. 2. London and New York: Routledge, 2009. 85-107. Print.

- The World Republic of Letters. Trans. M.B. DeBevoise. Cambridge: Harvard University Press, 2004. Print.

Chakraborty, Mridula Nath. "Rabindranath Tagore and World Literature." Perspectives on Literature and Translation: Creation, Circulation, Reception. Eds. Brian Nelson and Brigid Maher. New York: Routledge, 2013. 117-133. Print.

Collins, Michael. Empire, Nationalism and the Postcolonial World: Rabindranath Tagore's Writings on History, Politics and Society. New York: Routledge, 2012. Print.

Cordingley, Anthony, ed. Self-Translation: Brokering Originality in Hybrid Culture. London: Bloomsbury Academic, 2013. Print.

Damrosch, David. What is World Literature? Princeton: Princeton University Press, 2003. Print.

Ding, Ersu. Parallels, Interactions, and Illuminations: Traversing Chinese and Western Theories of the Signs. Toronto: University of Toronto Press, 2010. Print.

Driscoll, Beth. The New Literary Middlebrow: Tastemakers and Reading in the Twenty-first Century. New York: Palgrave Macmillan, 2014. Print.

Elias, Norbert. "Wandlungen der Wir-Ich-Balance." Die Gesellschaft der Individuen. Ed. Norbert Elias, Frankfurt: Suhrkamp, 1987. 207-316. Print.

Emerson, O.B. Faulkner's Early Literary Reception in America. Ann Arbor: UMI Research Press, 1984. Print. 
Engdahl, Horace. "Canonization and World Literature: the Nobel Experience." World Literature: $A$ Reader. Ed. Theo D'Haen, César Domínguez, and Mads Rosendahl Thomsen. New York: Routledge, 2012. 316-328. Print.

English, James. The Economy of Prestige. Cambridge: Harvard University Press, 2005. Print.

English, James F., and John Frow. "Literary Authorship and Celebrity Culture." A Concise Companion to Contemporary British Fiction. Ed. James F. English. Oxford: Blackwell, 2006. 39-57. Print.

Espmark, Kjell. The Nobel Prize in Literature: A Study of the Criteria Bebind the Choices. Boston: G.K. Hall, 1991. Print.

Fayen, Tanya. In Search of the Latin American Faulkner. Lanham: University Press of America, 1995. Print.

Feldman, Burton. The Nobel Prize: A History of Genius, Controversy and Prestige. New York: Arcade Publishing, 2000. Print.

Finn, Peter, and Petra Couvée. The Zhivago Affair: The Kremlin, the CLA, and the Battle over a Forbidden Book. New York: Pantheon, 2014. Print.

Flood, Alison. “Nobel Judge Attacks 'Ignorant' US Literature.” The Guardian. 1 October 2008. Web. 13 August 2015. <www.theguardian.com/books/2008/oct/01/us.literature.insular.nobel>.

Fo, Dario. "Contra Jogulatores Obloquentes (Against Jesters Who Defame and Insult)." Nobel Lectures, from the Literature Laureates, 1986 to 2006. New York: New Press, 2007. 129-143. Print.

Ginsburgh, Victor. "Awards, Success and Aesthetic Quality in the Arts." Journal of Economic Perspectives, 17.2 (2003): 99-111. Print.

Goldblatt, Howard. "A Mutually Rewarding yet Uneasy and Sometimes Fragile Relationship between Author and Translator." Mo Yan in Context: Nobel Laureate and Global Storyteller. West Lafayette, Indiana: Purdue University Press, 2014. 23-36. Print.

Gullin, Christina. "Translation and Acculturation: Reflections on Nadine Gordimer's Reputation in Sweden." Literary Translation: World Literature or "Worlding” Literature. Ed. Ida Klitgård. Copenhagen: Museum Tusculanum Press, 2006. 113-128. Print.

Gunder, Anna. "In the Wake of a Nobel Prize: On Modern Icelandic Literature in Swedish 19401969." The Invasion of Books in Peripheral Literary Fields: Transmitting Preferences and Images in Media, 
TranscUlturAl, vol. 8.1 (2016), 57-51.

http://ejournals.library.ualberta.ca/index.php/TC

Networks and Translation. Eds. Petra Broomans and Ester Jiresch. Groningen: Barkhuis, 2011. 105-116. Print.

Gyllensten, Lars. The Nobel Prize in Literature. Trans. Alan Blair. Stockholm: Swedish Academy, 1978. Print.

Heilbron, Johan. "Towards a Sociology of Translation: Book Translations as a Cultural WorldSystem." European Journal of Social Theory 2.4 (1999): 429-444. Print.

Hirata, Hosea. The Poetry and Poetics of Nishiwaki Junzaburo: Modernism in Translation. Princeton: Princeton University Press, 1993. Print.

Hoge, Warren. “Swedes Dispute Translation of a U.N. Legend's Book." The New York Times. 22 May 2005. Web. 14 August 2015.

Huggan, Graham. Postcolonial Exotic. New York: Routledge, 2001. Print.

Hume, David. "Of the Standard of Taste." The Philosophical Works of David Hume. Eds. T. H. Green and T. H. Grose. London: Longman, 1874-75 [1757]. Print.

Kalder, Daniel. “The 'Lost' Books of Alexander Solzhenitsyn.” Publishing Perspectives 10 Jan. 2010. Web. 12 August 2015.

Kertész, Imre. Sorstalanság. Budapest: Magvet'o, 1975. Print.

Kostelanetz, Richard. "The Ultimate Prize." The New York Times Book Review 86 (27 Sept. 1981): 3-4, 31-2. Print.

Lawall, Sarah. "Naguib Mahfouz and the Nobel Prize: Reciprocal Expectations." Naguib Mahfouz: From Regional Fame to Global Recognition. Eds. Michael Beard and Adnan Haydar. Syracuse: Syracuse University Press, 1993. 21-27. Print.

Leverence, John. Irving Wallace: A Writer's Profile. Bowling Green: Popular Press, 1974. Print.

Link, Perry. "Does This Writer Deserve the Prize?” The New York Review of Books. 6 Dec. 2012. Web. 2 August 2015.

Lovell, Julia. The Politics of Cultural Capital: China's Quest for a Nobel Prize in Literature. Honolulu: University of Hawaii Press, 2006. Print.

Margulis, Jennifer, and Peter Nowakoski. "Language." Postcolonial Studies at Emory. 22 April 2008. 
TranscUlturAl, vol. 8.1 (2016), 57-51.

http://ejournals.library.ualberta.ca/index.php/TC

Web. 14 August 2015.

Mazrui, Ali Al'Amin. The Politics of Gender and the Culture of Sexuality: Western, Islamic, and African Perspectives. Ed. Etin Anwar. Lanham: University Press of America, 2014. Print.

Morgan, Peter. "Translation and Dictatorship: the Case of Ismail Kadare." The AALITRA Review: A Journal of Literary Translation, Melbourne: Monash University, 2 (2010): 37-41. Print.

Mukherjee, Sujit. "Rabindranath into Tagore: the translated poet." Translation as Recovery. Ed. Meenakshi Mukherjee. Delhi: Pencraft International, 2004. 113-121. Print.

Ogden, Suzanne. Inklings of Democracy in China. Cambridge: Harvard University Press, 2002. Print.

Österling, Anders. “The Literary Prize." Nobel: The Man and His Prize. Ed. W. Odelberg. 3rd ed. New York: American Elsevier, 1972. 73-137. Print.

Palau de Nemes, Graciela. "Tagore and Jimenez: Poetic Coincidences." Rabindranath Tagore, 1861 1961: A Centenary Volume. Ed. Sahitya Akademi. New Delhi: Sahitya Akademi, 1961. 187197. Print.

Parks, Tim. "The Nobel Individual and the Paradoxes of 'International Literature'." The Times Literary Supplement. 20 April 2011. Web. 14 August 2015.

Parks, Tim, and Per Wästberg. "Do We Need the Nobel?: An Exchange." The New York Review of Books. 22 Dec. 2011. Web. 14 August 2015.

Pickford, Sue. "The Booker Prize and the Prix Goncourt: A Case Study of Award-winning Novels in Translation." Book History 14 (2011): 221-240. Print.

Ponzanesi, Sandra. The Postcolonial Cultural Industry: Icons, Markets, Mythologies. New York: Palgrave Macmillan, 2014. Print.

Riggan, William. "The Swedish Academy and the Nobel Prize in Literature: History and Procedure." World Literature Today. 55.3 (1981): 399-405. Print.

Ringmar, Martin. “'Roundabout Routes': Some Remarks on Indirect Translations.” Selected Papers of the CETRA Research Seminar in Translation Studies 2006. (2007): 1-17. Ed. Francis Mus. Web. 14 August 2015.

Rising, Malin. "Judge: Nobel Prizes Too 'Eurocentric"”. The Guardian. 6 Oct. 2009. Web. 14 August 2015. 
Roberts, Gillian. Prizing Literature: The Celebration and Circulation of National Culture. Toronto: University of Toronto Press, 2011. Print.

Spivak, Gayatri. Outside in the Teaching Machine. New York: Routledge, 1993. Print.

Thacker, Robert. Alice Munro: Writing Her Lives: A Biography. Toronto: Emblem, 2011. Print.

Thomas, Alfred. Shakespeare, Dissent and the Cold War. Houndmills, Basingstoke, Hampshire; New York: Palgrave Macmillan, 2014. Print.

Tolstoi, Ivan. "How Pasternak's Path to the Nobel Prize Was Paved by the CIA.” Radio Free Europe/Radio Liberty. 20 Feb. 2009. Web. 13 August 2015.

Tötösy de Zepetnek, Steven, and Louise O. Vasvári. "Introduction to Imre Kertész and Holocaust Literature." Imre Kertész and Holocaust Literature. Ed. Louise Olga Vasvári et al. West Lafayette: Purdue University Press, 2005. 1-10. Print.

Vanderauwera, Ria. "What Translation Can (and Should) Do for Little-Known Languages.” Language and Communication 10 (1990): 63-67. Print.

Wade, James. "The Nobel Prize and the Translation Problem.” Korea Journal 9.4 (1969): 4-6. Print.

Wang, Ning. "Cosmopolitanism and the Internationalization of Chinese Literature." Mo Yan in Context: Nobel Laureate and Global Storyteller. Eds. Angelica Duran and Yuhan Huang. West Lafayette: Purdue University Press, 2014. 167-182. Print.

wa' Thiong'o, Ngugi. Decolonizing the Mind: The Politics of Language in African Literature. London: Heinemann Kenya, 1986. Print.

Weissbort, Daniel. “Translation and Cheese-making.” PN Review 33.4 (2007): 11-12. Print.

"The Will". Nobelprize.org. Nobel Media AB 2014. Web. 14 February 2015.

Yeung, Jessica. Ink Dances in Limbo: Gao Xingjian's Writing as Cultural Translation. Hong Kong: Hong Kong University Press, 2008. Print. 